\title{
THE ROLE OF LOCAL VALUE IN GLOBAL SUSTAINABLE TOURISM DEVELOPMENT PARADIGM. THE CASE OF TOURISM IN BALI
}

\author{
I Ketut Budarma, Ketut Suarta. \\ State Polytechnic of Bali \\ budarmaketut@yahoo.com.au, suartaiketut@gmail.com
}

\begin{abstract}
From 1987 economic development is challenged with the sustainability paradigm that aims to promote a sustainable development of a triple bottom lines, economic, social and environmental. UNWTO and WTTC promoted Agenda 21 by stating that tourism stakeholders have to participate in sustainable development of the territories. The engagement of tourism businesses including hotels, equipped themselves with a number of tools such as CSR (Corporate Social Responsibility). By the impregnation and the stage of governmental actions, sustainable development becomes a global value. Thus, transnational hotels operating in Bali are required by Indonesian law since 2007 to integrate the CSR program, requiring them to bring benefit to the local community in a holistic sense. Transnational hotels are required to participate in local sustainable development, but also to meet the requirements of Balinese traditional theological philosophy, ecological and social known as Tri Hita Karana. This research therefore challenges the western paradigm of sustainability, which aspires to universalism by questioning its ability to integrate cultural specificity in the Balinese case, by combining reflective and pragmatic approach, focused more specifically on the particular case of transnational hotels. They are essential agents of the international tourism boom in Bali since 1970.
\end{abstract}

Keywords: sustainable development, tourism, corporate social responsibility (CSR), tri hita karana, transnational hotels.

\section{INTRODUCTION}

Balinese cultural resilience has been known for ages, it has been challenged by several pressures during the kingdom up to the present reformation era. The flexibility, the openness and the capacity to select, to adopt and to integrate foreign influences has enabled Balinese culture to withstand hitherto. Balinese social organizations such as traditional village, banjar (hamlet), subak (the irrigation system) etc. have become agents of cultural sustainability on the island. The multi layered organizations are strongly powered and controlled by Balinese cultural specificity, embodied by its philosophy of harmony, called Tri Hita Karana, living in pious harmony with God, with fellow-beings and with nature. The benefit of the multi-layered organizations is its integrity and 
commitment in safeguarding the culture, if one of them fails, other organization will backup.

The emergence of tourism in Bali since 1920s, has been a challenge for Balinese and it cultural specificity. It used to be a religious culture, dedicated to gods and the Balinese themselves for their spiritual wellbeing. Culture has been the most vital pull factor attracting tourists to visit the island, cultural sustainability goes hand in hand with tourism sustainability on the island. Culture has been utilized by both private sectors in tourism and governmental policy as the capital of tourism development. For Balinese in general, culture is an asset and also a capital for them to live on tourism. Tourism is manipulated in such a way to generate foreign exchanges and also used to sustain their culture for both, traditionally and commercially. The awareness of tourism stakeholders in Bali on the importance of cultural sustainability, has evoked them to integrate Balinese culture and the philosophy of harmony in their business strategy.

This paper examines if the existing local paradigm of sustainability called Tri Hita Karana (Living in harmony with God, Fellow being and Nature) and sustainable development can be aligned through tourism. The research focused on the transnational hotels' Corporate Social Responsibility programs in four tourist resorts in the island of Bali.

\section{Methodology}

\subsection{Problematic}

Tri Hita Karana is a theological philosophy used by Balinese to manage their harmonious relationship with God as the creator, with human being and with nature. All of those relationship done through rituals and ceremonies, the harmonious relationship is not merely physical and also metaphysical. This research proposes three problematic questions.

a. How can Balinese spiritual paradigm be aligned with sustainable development?

b. What role does tourism play in integrating the spiritual paradigm with global sustainable tourism?

c. What is the impact of the local spiritual paradigm alignment with sustainable development?

Those three operational problematic questions, are preceded by the author's initial presumption by putting forward three hypothesis.

a. Balinese spiritual paradigm has universal values, in regard with ecology conservation, both from extrinsic and intrinsic aspects, social and spiritual welfare. The paradigm is a new approach to sustainable development based on the local culture.

b. Tourism has an integrative roles, globalizing the local paradigm and localizing the international values of sustainable development.

c. The impact of the local spiritual paradigm alignment, with sustainable development is a hybrid value between locality and globalization as a specific model of Balinese sustainable development. 


\subsection{Method}

The method applied in this research is hypothetic deductive, based on several phase in comparing and confronting global paradigm of sustainable development with the actuality of a deep confrontation with Balinese conception of cosmology encompassing Balinese socio-cultural and theological conception of sustainability.

\section{Respondents}

The research needs both verbal and written information from closely related stakeholders both as the direct actors of sustainable tourism on the island, regulators and the targeted communities. Below are lists of the respondents who have given relevant information for the research. In relation with the data analysis, qualitative and quantitative technics are employed. The research carried out from 2013 to 2014 by collecting data from relevant resources. Below is the list of the respondents.

\begin{tabular}{|l|l|c|}
\hline \multicolumn{1}{|c|}{ No } & \multicolumn{1}{|c|}{ Respondents } & $\begin{array}{c}\text { No. } \\
\text { Respondents }\end{array}$ \\
\hline 1. & CSR managers of the 12 hotels & 12 \\
2. & Traditional chief of & 4 \\
3. & villages & 200 \\
4. & Communities living around the hotels & 1 \\
5. & Indonesian hotel and restaurant association & 1 \\
6. & Indonesian travel association & 2 \\
7. & Chief of subak ( Balinese traditional & 1 \\
8. & irrigation) & 222 \\
\hline Total & The director of subak museum & \\
\hline
\end{tabular}

\subsection{Research Field}

The research is focused on 11 transnational hotels and one state owned company which is responsible for Nusa Dua resort management. Those 12 establishments spread in four tourist resorts with its own specific characteristics. Nusa Dua where Melia Bali, The Westin and BTDC are located. Jimbaran a newly emergence resort where Alila Villa, Banyan Tree Hotel and Bali Intercontinental are situated. Two old tourist resorts were selected, Sanur and Kuta. Hyatt Sanur, The Conrad Bali, and Melia Benoa found in south eastern coast, while Dynasty, The Patra and Kartika Plaza set in the south-western coast, called Kuta.

\section{Literature Review}

\subsection{Another Conception of Sustainability? Tri Hita Karana Philosophy}

Originally tri hita karana is only a theological and sociocultural teaching originated from Balinese scriptures. The doctrine of the teaching is that God manifested in all of His creation, God has to be exalted through holy sacrifice and devotion in the form of rituals. The balance and harmonious relationship between humankind and God, between humankind with its fellow being and natural 
environment has to be maintained to reach supreme wellbeing and happiness. The teaching consists of spatial conceptions, physical and spiritual relation between humankind and the nature. Along with the rise of sustainable development issues, values that exists in the concept of tri hita karana, are considered relevant to the environmental and socio-cultural development. To expose the values of tri hita karana in response of sustainable development and deteriorating quality of the environment in Bali due to the tourism dominant development, THK movement was initiated in year 2000 ( Peters J. H and Wardana, 2013).

The THK movement has been fruitful to establish THK award certification board, to certify especially hotels to meet the criteria set by the board. The movement has been successful both nationally and internationally, THK award was recognised by UNWTO in 2004, it was stipulated in the preamble of Indonesia Tourism Law No. 10/ 2009 and in 2011 Bali's local government made tri hita karana award obligatory for all hospitality business operating in Bali. In this chapter the concept of tri hita karana will be reviewed especially in its relation with Balinese approach natural and social environment.

Tri hita karana conception and its co-trilogy approaches to nature manifested in six more practical devotion of human being into their environment at large. Those six devotional practice is called sad kertih, as illustrated by the chart below. Tri hita karana consisting of God, human and natural dimensions, extended in more detail in the conception of sad kertih. God dimension is not extended, natural dimension is extended into three parts namely ocean, flora and fauna and fresh water, and human dimension extended into two namely social and individual. The philosophy of tri hita karana mentioned that human has to be in harmony with nature without detailing with which nature. Sad kertih details that human being has to build relation with fresh water, flora and fauna and ocean. Those three parts of nature of course covering all organism living there, with which human being have to be associated as well. The extension from human dimension into social and individual environment is an extension that cause complication to understand especially when it is viewed from western conception of environment. The complication is that human body itself is considered as the environment by that individual.

\subsection{Towards a Meeting Solution, Crossing Balinese Culture and Sustainable Development with Western Conception.}

Scholars have done researches on Balinese strong relationship on their environment, natural environment, spiritual and social environment. How they perceive their presence in relation to gods, nature and their fellow beings, hence their happiness emanates as the fruit of their intricate harmonious relationship. Natural environment is seen both horizontally and vertically, both physically and metaphysically. Environment is always dealing with something physical, cultural, religious, social and psychological aspects (Belo 1935, Covarrubias 1937, Hauser Schàublin 1997, Hooykaas 1974, Howe 1980, James 1973, Ramseyer 1977, Reuter 1996 in Wassmann Jurg and Dasen Pierre R, 1998). Their strong relation with their environment at large, may benefit sustainable development taking place on the island, and can be well fitted with global conception or might be partly convergent and partly incompatible. Their pattern of relationship with their environment has resulted in various cultural and natural diversities that strongly 
lure both foreign and domestic visitors to visit the island. The question now is whether tourism companies in the island with their western sustainable development conception can be synergically used as a means of sustainable development.

Tourism internationally has become the largest and the most growing sector in the world of economic during the second half of $20^{\text {th }}$ century (Edington and Redman, 2000 in Tisdell Clem, 2000). The main objectives of tourism development based on World Tourism Organisation (WTO) are economic development, international understanding, peace, prosperity and universal respect for human right (Grey. H. Peter, 2000 in Tisdell Clem, 2000). The objectives of the tourism development as herein mentioned, encompass the tourism immobile asset located on the island of Bali. The main assets are nature, especially cultural landscape of Bali, Balinese culture and their livestyle (Picard, 2006). The viability of a tourist industry very much depends on the existence of some attractions for the visitors. Those attractions have to be different from the country of origin of the visitors. Bali since the birth of tourism, has offered its specificity of nature and culture. The appeal of the attractions is determined by the quality, location and perception of the visitors. In other word, asset is a determinant factor for the sustainability of tourism industry. The asset provides the distinguishing criteria, the distinguishing criteria then governs the economic value of the asset. The Crossing between Balinese Culture and Sustainable Development with Western Conception is actually a crucial effort between those two entities to sustain the viability of tourism on the island and sustain natural and cultural resources as the immobile asset of tourism. Consequently the transnational hotels operating in Bali have incorporate Balinese paradigm of sustainability, at the same time Balinese may adopt global paradigm to enrich their indigenous culture in the domain of sustainable development.

Globalization of transnational hotels through the flow of transnational investment and of course with their highly interconnected global chain brought their global paradigm, and it was expected to be automatically effective in Bali, since Indonesia is a member of UNWTO and WTTC and it has ratified global convention, and Indonesia's legal system has to comply with it. Complication then arise when those global paradigms crossed with local Balinese paradigm in sustaining livelihood of Bali. The question is "Can those transnational hotels just ignore the local complex paradigms, only comply with Indonesia's national legal system?" or "Should they incorporate local paradigms which are practiced in Balinese traditional religious activities?" Global paradigm of sustainable development is always in the business and profit making interest, focusing on material welfare while Balinese paradigm focuses on the spiritual wellbeing and non-lucrative. The fact that practical concept of Balinese paradigm has made the island known as the most prominent cultural tourism destination in Indonesia, and the fact has attracted both visitors and investors including those international hotels operate in Bali.

The integration and even syncretism of local values in touristic sustainable business practices is even obligatory for transnational hotels in Bali, based on agenda 21 for the travel and tourism which was launched in 1996. One of the sustainable frame works of sustainable tourism is that tourism development should recognize and support the identity, culture and interests of indigenous 
peoples ( Agenda 21 for the Travel \& Tourism Industry, 1996). This framework applied in Bali through their Corporate Social Responsibility (CSR), popularly called CIP or community involvement project. One of the frame works related to nature (Travel \& Tourism should assist people in leading healthy and productive lives in harmony with nature) is part of Balinese wisdom philosophy Tri Hita Karana, live in harmony with nature. The question is that leading healthy and productive live in harmony with nature in the western conception is totally different from Balinese approach to nature. In the western concept in harmony with nature signifies proportional utilisation of nature based on its carrying capacity (Harris Rob ital. 2003). While in harmony with nature in the singularity of Balinese cultural approach is to preserve the spiritual aspects of nature through rituals, three main rituals dedicated to nature are wana kerthi (ritual dedicated to green vegetation and its ecosystem), danu kerthi (ritual dedicated to fresh water resources) and samudra kerthi (ritual dedicated to saline water resources), ( Wiana Ketut, 2007).

\section{Results}

Those 12 tourism establishments are certified by Tri Hita Karana Award, for their compliance with the local legal systems and conventions, while for their compliance with international standard, they are certified by EarthCheck. The research focuses more on the hotels' effort in aligning Balinese spiritual philosophy of harmony called tri hita karana, and its contribution to Bali's sustainable tourism development. The important role of Balinese culture, rooted in Hinduism teaching, where community and nature are integrated in spiritual activities, have been embedded by Transnational Hotels operating in the island in their CSR program as a share value. Balinese culture does not have only traditional and religious value, but also economic value, which enables Balinese to live on tourism through their cultural exposition. Balinese traditional way to treat social life and nature is integrated to the global paradigm, but local value system is still dominant, giving specific characteristic to the hotels' products.

\subsection{Balinese Conception of Cosmology is Strongly Aligned in Bali's Sustainable Tourism Development.}

Tri Hita Karana as a spiritual philosophy, strongly followed by Balinese in their day to day life practices, has controlled all courses of their activities both traditionally and professionally. The tri harmonious relationship is manifested in spatial conception called tri mandala (three spaces). They have sacred space, where temples and shrines are located, the space is called utama mandala. Spaces where houses, offices and markets are situated is called madya mandala, the space commonly referred as a residential space. The space where garbage is kept and recycled, and the space where recreational is done is called nista mandala or a profane space.

Transnational hotel operating on the island of Bali is obliged to follow the conception of the traditional spatial division. All hotels built Hindu's temples in the sacred part of the hotel, a space in the direction of the highest mountain in Bali (Mount Agung), and the sunrise. Balinese believe that mountain where gods abide and the east where the sun rises are sacred directions. The temple is a place of worshiping where the hotels ask for blessing, and demonstrates the message that 
all stakeholders of the hotel build spiritual harmony as the foundation of their businesses. Guest rooms and restaurants are built in the madya mandala, while swimming pools and water treatment are located in the nista mandala.

The lay out of the hotels' building is one of the important criteria set by Tri Hita Karana award assessment, known as THK award. CSR in the context is the participation of the hotels in sustaining Balinese cultural architecture and values in the hotel buildings. The name of the guest rooms and buildings are also expected in Balinese. The lay out of the hotels and their architectural elements have contributed local Balinese atmosphere for their guests, soon after their arrival in the hotels. They get at least two benefits from the adoption of the cultural elements; they are in compliance with the requirements of the THK award, and also maximization of their guests' satisfaction and cultural experiences.

The adoption of the Balinese cosmological philosophy in transnational hotels of the island, is in line with tourism global code of ethic, where transnational hotels are compulsory to respect and integrate local culture to their businesses. The traditional spatial code have made the hotels set a special area of their property green and unbuilt. The use of water, energy and the production of waste can be efficiently managed, in accord with international standard set by EarthCheck.

\subsubsection{Hotels' Contributions to Balinese Religious Activities}

All hotels agreed that the viability of their business in Bali depends on the sustainability of Balinese culture. The key success of Bali's sustainable development lays on Balinese traditional villages, all of their activities based on the spiritual philosophy tri hita karana, where community and nature are strongly related to religious ceremonies, in their effort to sustain harmonious relationship. Bali, an island of a thousand temples, characterized by vibrant temple festivals and ceremonies has been demonstrating to the world that religion is playing an important role in their daily life.

Considering the important role of the traditional villages in Bali, transnational hotels have committed to work with them and bound themselves in official memorandums of understanding. The hotels and the villages demonstrate a strong obligation to work together in Bali's sustainable tourism development, based on the spiritual values of the locals, supporting religious activities, since Balinese spiritual wellbeing is paramount for their holistic life. Hotels under the banner of CSR created another program called Community Involvement Program (CIP), which enable them to access and involve more people in their global sustainable development campaign by aligning local paradigm.

\subsubsection{The hotels provide access for local to participate in their business.}

All hotels as part of their CSR program provide access for local community to participate in the hotel businesses. They provide space for local vendors to sell their products within the hotels' premises. Some hotels used value-share approaches by building cooperation with a group of Balinese artisan to produce certain products, then the hotels buy them for their clients.

\subsubsection{Hotels' contributions to Balinese social life and culture}


Balinese culture has been treated as the capital for Bali's tourism development, with its local specificity, it can attract tourists to come to the island. Consequently the viability of the hotels' businesses has been strongly depending on the sustainability of the local culture. The interdependent relationship between tourism, culture and community's economic development has been demonstrated by the hotels' CSR programs in supporting preservation and development of Balinese local culture, both within the hotels on in the communities. In return local Balinese has been utilizing their culture as the capital to be benefitted by tourism.

\subsection{Tourism has an integrative roles, globalizing the local paradigm and localizing the international values of sustainable development.}

Corporate Social Responsibility of the transnational hotels on the island of Bali has been strongly underpinned by the conception of three harmonious relationship, aiming at the spiritual wellbeing, and social welfare within wellpreserved nature. The local genius has been carefully arranged and integrated with the global paradigm of sustainable development, to meet the demand of the local and global community, since tourism practice is characterized by mutual acceptability between local and global value, or tourism practice never happens without local acceptability.

CSR activities of the hotels have not only helped local community improve their living standard but also promote their local genius to be another approach of sustainable development. Tri hita karana as a result has been recognized by UNWTO since 2012, the principles of the harmony has been demonstrated in the Indonesian Tourism Laws. Conversely international values on sustainable development have also been introduced to Balinese, especially environmental management system. The introduction of the international values and practices done through education and dissemination program in the communities.

The role of tourism is integrating local spiritual paradigm of sustainable development with the global one. The slice between the two paradigms is mutual integrated approach of sustainable development, benefiting both local community as the steward of the Balinese culture, and tourism enterprises as the consumer, at the same time as the agent of sustainable development.

\subsection{Hybrid value system between locality and globalization as a specific model of Balinese sustainable development.}

CSR carried out by transnational hotels in Bali promoted through Community Involvement Project (CIP). Their CIP is encompassed by the spiritual paradigm, tri hita karana, their main objective is to involve local community in their global sustainable tourism mission as underpinned by global code of ethic in tourism, by respecting local culture. Traditional institutions like traditional villages and traditional hamlets are incorporated, since those institutions are the agents of Balinese culture sustainability.

Most of the activities focused on Balinese culture preservation and development, both within the hotels (Hindus temple in the hotels, traditional dances and music in the hotels, daily offering in the hotels, Balinese architecture 
in the hotels), and outside the hotels (supporting traditional villages to preserve and develop local cultures, contributing to religious rituals, sponsoring cultural event in villages etc.). The CIP is expected to have mutual benefit for both tourism sectors and Balinese community at large. The viability of tourism businesses in Bali are strongly rely on the sustainability of Balinese culture at large, since culture is the biggest pull factor for travelers visiting the island. For the local community, CIP promotes awareness that their culture has an important value to sustain tourism on the island as well as to sustain their religious culture for their spiritual wellbeing.

Global values of sustainable development, where socio-cultural and ecology associated with economic development has been assimilated with local spiritual values where socio-cultural and ecology dedicated to spiritual wellbeing. The effect of the assimilation is then material welfare and spiritual wellbeing, where Balinese still live on their traditional faith and culture, hence tourism business viability emanates.

Both transnational hotels and Balinese confirm that Balinese culture specificity is of a great prominence for making tourism on the island viable and durable. The focal idea is to keep the specificity of Balinese culture within the global framework of transnational hotels' businesses in the island. The two value systems works in hybrid manner, with mutual fortification creating value added products (Balinese culture has global property, global product of the hotels has local property), which at the end produces wealth for both.

The investment of the hotels on their CSR program is to prevent the homogenization of local culture by the global values. The homogenization will eliminate the specificity of the culture, which causes the downturn of tourism business in the island. Local value system has to be fortified to keep its role as meta-system that control global value system as sub-system, on the other words when local value system oppressed by the global one, local value will be homogenized, then Bali has no specific characteristic, the tourists will leave the island.

\section{CONCLUSION}

The CSR in the hotels has rigorously promoted local spiritual paradigm (tri hita karana) as another breakthrough to sustainable development in Bali. The spiritual paradigm encompasses interdependent harmonious relationship between human being and God, other human being and nature, socio-culture and nature are integrated into spiritual wellbeing. Balinese three bottom lines (God, man and nature) can enrich three bottom lines of global sustainable development (Economy, socio-culture and nature). The integration of the local paradigm with global sustainable development conception results in four bottom lines, spiritual, economic, social and ecilogical wellbeing.

The integration of Balinese spiritual paradigm in CSR activities of the transnational hotels operating in Bali, has a strong effect of assimilation between local and global values of sustainable development. The spirit of exposing the local paradigm in international arena has been very obvious since year 2000, when tri hita karana foundation initiated by academicians, culturist and tourism stakeholders. The exposition of the local paradigm has been successful, demonstrated by UNWTO recognition in 2004, as one of the local genius, 
deployed in the promotion of sustainable development conception and practices. The internationalization of the local paradigm, has promoted participatory and inclusive approaches, since local community's aspiration is well accommodated. They are the object of the sustainable development, but also the subject who need to adopt global paradigm in their local approaches.

The alignment and globalization of the local paradigm in Bali's sustainable development, has created a new model or approach of sustainable development with Balinese culture singularity. Sustainable development in Bali is strongly characterized by sustainability of sacred places and its spiritual properties. Adoption of Balinese spiritual culture in the hotel's premises, implies that the hotels' effort in sustaining Bali is not merely physical but also the metaphysical aspects of their business. Spiritual wellbeing creates harmony and productivity for their holistic needs in sustaining their livelihood as Balinese.

\section{REFERENCES}

Abrams, F.W. (1951). Management's Responsibilities in a Complex World. Harvard Business Review, 29 (3), pp. 29-34.

Adi Wirawan Made (2011). Tri Hita Karana: Study of Theology, Ecology and Sociology. Paramita, Surabaya.

Atkinson G. 1997. Measuring Sustainable Development: Macroeconomics and the environments. Edward Elgar, Cheltenham, UK.

Agenda 21 for the Travel \& Tourism Industry, 1996, http://wwwv1.agora21.org/johannesburg/rapports/omt-a21.html

Adrian Vickers (1996). Bali A Paradise Created. Periplus Edition, Singapore.

Ashley, C, 2007. The role of tourism sector in expanding economic opportunity. Harvard University.

Baron, D.P., (2001). Private politics, corporate social responsibility, and integrated strategy, Journal of Economics and Management Strategy, 10, pp. 7-45.

Beaver Allan, 2002. A dictionary of Travel and Tourism Terminology. Cabi Publishing, Wallingford, UK.

Burke, L., \& Logsdon, J. M. (2008). How corporate social responsibility pays off. In A. Crane, D. Matten \& L. J. Spence (Eds.), Corporate social responsibility: Readings and cases in a global context (pp. 420- 432). London: Routledge 
Bruce Mitchell, 1994. Sustainable Development at the Village Level in Bali, Indonesia. (Human Ecology Vol; 22, No. 2 1994). Premium Publising Corporation

Bramwell, B., Henry, I., Jackson, G. \& Van Der Straaten, J. (1996): A framework for understanding sustainable tourism management. In: Bramwell, B., Henry, I., Jackson, G., Prat, A., Richards, G. \& van der Straaten, J (eds.). Sustainable Tourism Management: Principles and Practice. Tilburg University Press. Tilburg, pp. 23-71.

Barnett. E and Casper M. 2001. Definition of social environment. American Journal of Public Health Vol. 91, No. 3, 2001.

Carroll, A.B. (1991). The Pyramid of Corporate Social Responsibility: Toward the Moral Management of Organizational Stakeholders. Business Horizons, 34, pp. 39-48.

Carroll, A.B. (1994). Social issues in management research: Experts' views, Analysis and commentary. Business and Society, 33, pp. 5-29.

Camelia Tepelus (2010): Corporate Social Responsibility in Tourism. Woodeaton, Oxford.

Chon S.K.\& Oppermann 1997. Tourism in Developing Countries. Alden Press, Oxford. UK

David A. Fennell 2006. Tourism Ethics. Channel View Publications, NY, USA

Davidson and Handley, 2007. The Revival of Tradition in Indonesian Politics: The deployment of adat from colonialism to indigenism. Routledge, 2 Park Square, Milton Park, Abingdon, Oxon OX14 4RN).

Dalem Raka et al, 2007. Kearifan Lokal dalam pengelolaan lingkungan hidup (Local Wisdom in managing environment). Udayana University. Denpasar.

Dive-the-world (2010). From Dive the World website: <http://www.divetheworld.com/tourist-information-indonesia-bali.php> (retrieved May 13, 2011).

Dodds \& Joppe (2005). CSR in the Tourism Industry? The status of and Potential for Certification, Codes of Conduct and guidelines. Worldbank.org/Reources/CSR_in_tourism.

Donaldson, T. and Preston, L.E. (1995). The stakeholder theory of the corporation: Concepts, evidence, and implications. Academy of Management Review, 20, pp. 65-91. 
Drucker, P. (1984). The new meaning of corporate social responsibility. California Management Review, 26, pp. 53-63.

Ducroux Anne-Marie, 2002. Les Nouveaux Utopistes du déveleloppement durable. Editions Autrement, Paris.

Dwyer Larry et al. 2012. Method of research in tourism. Edward Elgar Publishing Limited. UK.

Edy Yusuf Nur Samsu Santosa, 2003. Peran Desa Adat dalam Pengembangan Pariwisata di Bali.(The role of traditional villave in developing tourism in Bali). Journal Aplikasi llmu-ilmu Agama, Vol. IV, No. 2 Desember 2003

Eber, S. (ed.) (1992). Beyond the Green Horizon: A Discussion Paper on Principles for Sustainable Tourism. Tourism Concern \& World Wildlife Fund.

Edington and Redman, 2000. Economy and TourisM in Tisdell Clem, 2000. The Economy of Tourism Volume I. Edward Elgar Publishing Limited. Cheltenham. UK

Eiseman 1990. Bali: sekala and niskala. Berkeley, California: Periplus Editions, Inc.

European Committee for Social Cohesion, 2004. A new strategy for Social Cohesion. Uni European workshop.

Freeman, R. E. (1984). Strategic management: A stakeholder approach. Boston:Pitman

Freeman, R. E. (1984). Strategic management: A stakeholder approach. Pitman, Boston (MA).

Frederick, W. (1986). Toward CSR; Why Ethical Analysis is indispensible and Unavoidable in Corporate Affairs. California Management Review, 28, pp. 126-141.

Finn Mick et al , 2000. Tourism and Leisure Research Methods : Data collection, analysis and interpretation. Pearson education limited, Essex, England.

Friedman, M., (1970). The Social Responsibility of Business is to Increase its Profits. The New York Times Magazine, September 13, 1970. Url: http://www.colorado.edu/studentgroups/libertarians/issues/friedman-socrespbusiness. html accessed online on the 20th Jun 2009

Ferbianty Dieny, 2007. Sejarah Pariwisata Indonesia (The History of Tourism in Indonesia). Institut Teknologi Bandung, Indonesia. 
Garriga, E. and Mele, D. (2004) Corporate social responsibility theories: Mapping and territory. Journal of Business Ethics, 53, 51-74.

Gouil Hervé, 1999. Entreprendre en Economie Sociale: Sens des affarires ou Affaires de sens. 401 Sons. Paris.

Grootaert and Bastelaer, 2001. Understanding and Measuring Social Capital: A Synthesis of Findings And Recommendations from the Social Capital Initiative. World Bank. Washington DC.

Graeme S. MacRae, 1997. Economy, Ritual and History in Balinese Tourist Town. University of Auckland.

Geertz, H. 1980. Negara. The Theatre State in Nineteenth Century Bali, Princeton University Press, Princeton.

Hal Hill, 1994. Indonesia's New Order: The Dynamic of Socio-Economic Transformation. Allen and Unwin, NSW Australia.

Hart, S. L., \& Milstein, M. B. (2003). Creating sustainable value. Academy of Management Executive, 17(2), 56-67.

Haruya K, 2005. Regional Autonomy in progress: A Case Study in Bali 20012003. Asian and African area studies. 5(1), 46-57.

Henk Schulte Nordholt, 1991 : State, Village and Ritual in Bali. A historical Perspective. VU University Press, Amsterdam.

Hans Dreter Seibel, 2010: Cultural and Religious Foundation of Customary Financial. Institution, Kumerian Press, Virginia

Hooker, C.A. 1992. Responsibility, Ethics and Nature. In Cooper, D.E and Palmer, J.A The Environment in question: Ethics and Global Issues. London: Routledge.

Jafar Jafari, 2000.Encyclopedia of Tourism. Rouledge, New York

Jeff Lewis and Belinda Lewis, 2009. Bali's Silent Crisis Desire, Tragedy, and Transition. Lexington Book, UK.

J.R Brent Ritchie and Geoffrey I.Crouch, 2003. The Competitive Destination: A sustainable Tourism Perspective. Cabi Publishing Oxon, UK.

Julia and Meaton 2014. Corporate social responsibility (CSR) public policy in Indonesia: profile, state of the art and the key motive. ISBN: 978-967-570514-4. WEBSITE: www.internationalconference.com.my 
Katryn Webster, 2000. Environmental Management in the hospitality Industry: A guide for students and managers. Cassell, Willington House, London.

Krisna Anand, 2008. Tri Hita Karana: Ancient Balinese Wisdom for Neo Humans.Anand Krisna Global Co-operation, Jakarta..

Luu Trong Tuan, 2011. Corporate Social Responsibility and Sustainable Tourism. Business and Economic Research ISSN 2162-4860 2011, Vol. 1, No. 1: E4

Lee S. \& Park S-Y. (2009) Do socially responsible activities help hotels and casinos achieve their financial goals? International Journal of Hospitality Management Vol. 28 p. 105-112

Lewis Jeff, 2009. Bali’s Silent Crisis. Lexington Book, Plymouth. UK

Martin Yves-Jean, 2002. Dévevelopement Durable? Doctrines, Practique Evaluations.IRD Editions. Paris.

McKean, Philip (1989). Toward Theoretical Analysis of Tourism: Economic Dualism and

Cultural involution in Bali. pp 119-36 Valene Smith (Ed) Host and guest: The anthropology of tourism. Philadelphia, University of Pennsylvania press pub. 1977

McKean, 1973. Cultural Involution: Tourists, Balinese and the process of modernization in an anthropological perspective, tesis $\mathrm{PhD}$ Brown University in Picard 2006. KPG, Jakarta.

Mieczkowski, 1995 Environmental Issues of Tourism and Recreation, Lanham, MD. University Press of America.

McWilliams, A., Siegel, D.S. and Wright, P.M. (2006). Corporate social responsibility: strategic implications. Journal of Management Studies, 43 (1), pp. 1-18.

McCool F.S and Moisey Neil. R. 2001. Tourism, Recreation and Sustainability: Linking culture

Nash, D. 1996. Anthropology of tourism. Oxford: Elsevier Science

Nord Teresa, 2006. Corporate Social Responsibility in the hotel industry: A Cross Cultural Perspective, Stockholm University.

Onyx J and Benton, P, 1995. Empowerment and aging: Towards honoured Places for Crones and Sages in community empowerment. London:Zed Books. 
Orlitzky, M., Schmidt, F., \& Rynes, S. (2003) Corporate Social and Financial Performance: A Meta-analysis Organization Studies 24(3); 403-441

Onofre Martorell Cunill,2005. The Growth Strategies of hotel chains: Best business practice by leading companies. The Haworth hospitality press, Binghanton, NY

Parsons, T.: 1961, 'An Outline of the Social System', in T. Parsons, E. A. Shils, K. D. Naegle and J. R. Pitts (eds.), Theories of Society (Free Press, New York).

Pigram, J. (2001). Water resources management in island environments: The challenge of tourism development. Tourism (Zagreb), 49(3), 267-274.

Picard M., 1992, Bali: tourisme culturel et culture touristique, L'Harmattan, Paris.

Picard M, 2010, "Bali: the discourse of Cultural Tourism.", EspacesTemps.net, Textuel, 08.04.2010, http://espacestemps.net/document8152.html

Pickel Sylvine Chevalier and Evans R.2014. Sustainable rural development? Promising Elements of sustainable practices in Equin Tourism. In Dasper K 2014. Rural Tourism: An international Perspective. Cambridge Scholar Publishing, Newcastle.

Petra Jordan (2002). Enhancing the Economic Benefits of Tourism for Local Communities and Poverty Alleviation. World Tourism Organization Madrid, Spain.

Peters J. Hendrik \& Wardana W (20013). Tri Hita Karana: The Spirit of Bali. Gramedia, Jakarta.

Priskin Julianna, 2009. Développement Durable et Tourisme : Un Portrait International. Chaire de tourisme Transat ESG UQAM et ministère du Tourisme du Québec

Porter, M. 2009. Strategy and Society: From CSR to Creating Shared Value, Presentation at the Inner City Capital Connections (ICCC), New York City, Nov.19, 2009

Py Pierre, 2002. Le Tourisme: Un phénomène économique. Les études de la documentation Française.

Ramseyer Urs, 2002. The Art and Culture of Bali. Museum der Kulturen, Bassel. Switzerland

Ransley. $\quad$ M. 2012. Sustainable Tourism Practices. https://www.academia.edu/4820716/Sustainable_Tourism_Practices 
Ric Olivier Dubigion (2002). Met en Practique le developement durable. Paris hter, L (1993) Tourism Policy-making in South East Asia, 179-99 in M. Hitchcock. V.T. King, and M.J.G Parnwell, Tourism in south East Asia. New York, Routledge. Provence, Nîmes.

Teo Peggy, Chang T.C and Ho.K.C 2001. Interconnected world. Tourism in South East Asia.Pergamon, Elsevier Science, Amsterdam.

Tang Janeen 2004. A Case Study of A Hotel Solid Waste Management Program in Bali, Indonesia. Waterloo University, Ontario, Canada.

Travor H.B. Sofied 2003. Empowerment for Sustainable Tourism Development. Elsevier Science Ltd. Kidlington, UK.

Teresa Nord (2004). Corporate Social Responsibility in Hotel Industry : A cross culture perspective. Stockholm University, School of Business.

UNWTO (2003). Djerba declaration on tourism and climate change.

Violier Philippe, 2013. Le tourisme un phénoméne économique. Les études de la documentation française.

Warren Carole, 1998. Whose Tourism? Balinese Fight Back. Inside Indonesia 54. 1998

Willard A. Hanna (2004). Bali Chronicles. Periplus, Singapore

Wall Geoffrey, 1996.Perspective on Tourism in selected Balinese Villages. Anal of tourism research. Vol.23 no.1 p. 123-127. Elsevier Science. Great Bretain.

Weaver. D. 2006. Sustainable theory and practice. Elsevier ButterworthHeinemannLinacre House, Jordan Hill, Oxford OX2 8DP

Wiana Ketut, 2007. Kearifan Lokal Dalam Mengelola Lingkungan Hidup (Local Wisdom in managing environment. Udayana University, Denpasar.

Yanti Triwandiantini Koester, 2007. Corporate Social Responsibility in Indonesia Building internal corporate values to address challenges in CSR Implementation. Jakarta, Indonesia. 